\title{
DETERMINATION OF SOIL SHEAR MODULI AT DEPTHS BY IN-SITU VIBRATORY TECHNIQUES
}

by

\author{
R. F. Ballard, Jr.
}

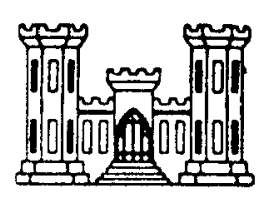

December 1964

Sponsored by

Air Force Special Weapons Center

Kirtland Air Force Base, New Mexico

Conducted by

U. S. Army Engineer Waterways Experiment Station CORPS OF ENGINEERS

Vicksburg, Mississippi 
$4=$

THE CONTENTS OF THIS REPORT ARE NOT TO BE USED FOR ADVERTISING, PUBLICATION, OR PROMOTIOHAL PURPOSES 


\section{Foreword}

The investigation reported herein was authorized by the Air Force Special Weapons Center (SWKRB), Kirtland Air Force Base, New Mexico, in Project Order PR630545, 16 August 1963, transmitted by letter to the U. S. Army Engineer Waterways Experiment Station (WES) dated 21 August 1963, subject "Project Order Number AF(29-601)-64-PO-2" (see Appendix A). Personnel of the Soils Division, WES, who were actively concerned with the investigation were Messrs. W. J. Turnbull, A. A. Maxwell, R. W. Cunny, Z. B. Fry, R. F. Ballard, Jr., J. I. Decell, and J. Fowler. This report was prepared by Mr. Ballard.

Col. Alex G. Sutton, Jr., CE, was Director of the WES at the time of the investigation and during the preparation of this report. Mr. J. B. Tiffany was Technical Director. 


\section{Contents}

\section{Page}

\section{Foreword}

iii

Summary . . . . . . . . . . . . . . . . . . . . . . .

vii

Purpose and scope of Study

Test Sites, Equipment, and Procedures . . . . . . . . . . . . . I

Location and description of test sites . . . . . . . . . . . I I

Equipment and test technique . . . . . . . . . . . . . 2

Eruations Used in Data Reduction . . . . . . . . . . . . . . . 4

Test Results . . . . . . . . . . . . . . . . . . . . . . . 6

Fixed-mass vibrator . . . . . . . . . . . . . . . 6

Variable-mass vibrator . . . . . . . . . . . . . . . 77

Discussion . . . . . . . . . . . . . . . . . . . . . . 8

Summary of Results and Conclusions . . . . . . . . . . . . . . 8

Tables 1 and 2

Plates $1-8$

APETIDIX A: FROJECT ORDER • • . . . . . . . . . . . . . . . . A AI 
Summary

The tests described herein were conducted to investigate the possibility of determining by in-situ field measurements the dynamic moduli of soils at depths approaching or exceeding $100 \mathrm{ft}$. Tests were performed at several sites representative of various soil materials ranging from sand to rock. During the test program, various mechanical and instru.. mentation improvements were made in test equipment. Specifically, the hydraulic-powered, fixed-mass vibrator initially used was replaced by a variable-mass vibrator, and a double-amplification technique vas utilized in conjunction with a low-frequency band pass filter to increase the amplitude and quality of the transducer signal.

Data were acouired utilizing the fixed-mass vibrator at three sites: Eglin Aix Force Base, Fla., in sand; Waldorf, Md., in cohesive soil; and Frenchman Flat, Nev., in cohesive soil. Wave penetration at these sites extended to depths of 20,37 , and 45 ft, respectively.

After construction of the variable-mass vibrator, data vere acquired with this vibratox at four sites: U. S. Army Engineer Waterways Experiment Station, Vicksburg, Miss., in cohesive soil; Sacramento Peak, N. Mex., in rock; and Buckboard Mesa and Area 15 at the Nevada Test Site, Nev., both in rock. Investigational depths attained at these sites were 120, 86, 90, and $170 \mathrm{ft}$, respectively. Although the variable-mass vibrator with improved instrumentation was not tested on sand, results of tests on other materials indicate that depths greater than the 20-ft depth investigated at Eglin with the fixed-mass vibrator can almost certainly be penetrated with the variable-mass vibrator. 


\section{Purpose and Scope of Study}

1. The purpose of this study was to investigate the possibility of measuring propagated. shear waves at depth from surface-induced vibrations. The desired final product of the research effort was the capability of determining the shear moduli of soil in a continuous profile to depths approaching or exceeding $100 \mathrm{ft}$. As stated in the "Statement of Work for Vibratory Soil Experiments" prepared by the Air Force Weapons Laboratory (see Appendix A), available equipment, personnel, and field sites were to be used in examining the feasibility of increasing the heretofore comparatively shallow depths of vibratory soil investigations by modifying existing equipment, refining measuring techniques, or both.

\section{Test Sites, Equipment, and Procedures}

Location and

description of test sites

2. Data collected at several field sites during dynamic soils investigations performed before or concurrently with this study were used in this study when applicable. In addition, tests were made at the Waterways Experiment station (WES) to check out equipment developed or modified to meet the objectives of this investigation. The sites at which these data were obtained are described below.

3. Eglin. The Eglin test site is located within the confines of the main base at Eglin Air Force Base, Fla., near Building 620. Boring data indicate that the soil material in this location consists of tan and yellow, poorly graded sand to a depth of $16 \mathrm{ft}$ and yellow, poorly graded sand with traces of silt from $16 \mathrm{ft}$ to a depth of $25.5 \mathrm{ft}$, which is the extent of boring data.

4. Waldorf. This site is the former Accokeek Nike-Ajax Site A-45, located approximately 5 miles southwest of Waldorf, Ma. The area consists of gently rolling terrain, and the soil at the site consists of the 
following successive layers: 1 to 2.5 ft of $\mathrm{fill}$ and topsoil, 3 to $5 \mathrm{ft}$ of brown sandy clay, 4 to $8 \mathrm{ft}$ of sand and gravel, $6 \mathrm{ft}$ of firm, tan silty clay, and 8 to $12 \mathrm{ft}$ of soft sil.ty clay with fine sand underlain by a stiff, gray silty clay extending to a depth of $80 \mathrm{ft}$.

5. Frenchman Flat. The test site is located approximately 15 miles north of Mercury, Nev., in an area referred to as Frenchman Flat. Terrain in this area is flat and dusty with no veretation. Borings indicated that the soil is a tan silt, hard and friable, with some variation in soil structure, cementation, and streneth to a depth of 55 ft.

6. WES. The WES test site is located vithin the confines of the reservation at Vicksburg, Miss. Soil at the site is a uniform silty clay (loess) to a depth of approximately $20 \mathrm{ft}$. From a depth of $20 \mathrm{ft}$ to about $100 \mathrm{ft}$, a bluish clay is predominant. Limestone is encountered at approximately $100 \mathrm{ft}$.

7. Sacramento Peak. The Sacramento Peak site is Located atop Sacramento Mountain near Clouderoft, N. ICx. Soil materiala at this site consist of a 1 - to 2 -ft layer of topsoil overlying fractured dolomitic limestone which extends to a depth of at least $236 \mathrm{ft}$, the maximum depth of borings made at this site.

8. Buckboard Mosa. The Bucliboard Mesa wite is located approximately 50 miles northwest of Mercury, Nev., within the confincs of the Nevada l'est Site. Subsurface materials predoninant in this arca are prinarily dense basalt and lenses of vesicular basalt occurring in random patterns. Borings indicate that the vase of the basalt is approxinately $150 \mathrm{ft}$ below surface level, at mich point a light tan turf is encountered.

9. Area 15. Area 15 is located approxinately 50 miles north of Nercury, Nev., within the confines of the Nevada Test aite. The material at this site consists of a relutively homoreneous shatum of granite diorite which extends from the surface to a depth of approsimately 300 1tt (the depth of available borchole information).

Equipment and test technique

10. Fixed-mass vibrator. The fixed-mass hydrutic vibrator was constructed by the WIS in 1962. A complete description of the vibrutor 
and its auxiliary equipment was presented in a recent WES publication.* After tests with this vibrator had been conducted at several locations, it was evident that the data collected permitted determining shear and compression moduli to depths averaging approximately $30 \mathrm{ft}$, or nearly double the depth formerly attainable with the electromagnetic vibrator.

11. Variable-mass vibrator. The requirement for greater depth peretration in this study prompted numerous improvements in the fixedmass vibrator, the design of more sophisticated instrumentation, and led finally to the construction of a variable-mass vibrator. A block diagram of the instrumentation setup and a component listing of the improved and currently used apparatus, which has replaced the fixedmass vibrator, are shown in plate 1. For comparative purposes, table 1 presents force capabilities of the fixed-and variable-mass vibrators, respectively. Table 1 readily shows the advantages of the variable-mass vibrator in terms of available force capabilities, especially in the lowerfrequency range which is associated with long wavelengths and therefore greater depth penetration. The vibrator is trailer-mounted and towed behind an instrumentation van as shown in fig. 1 .

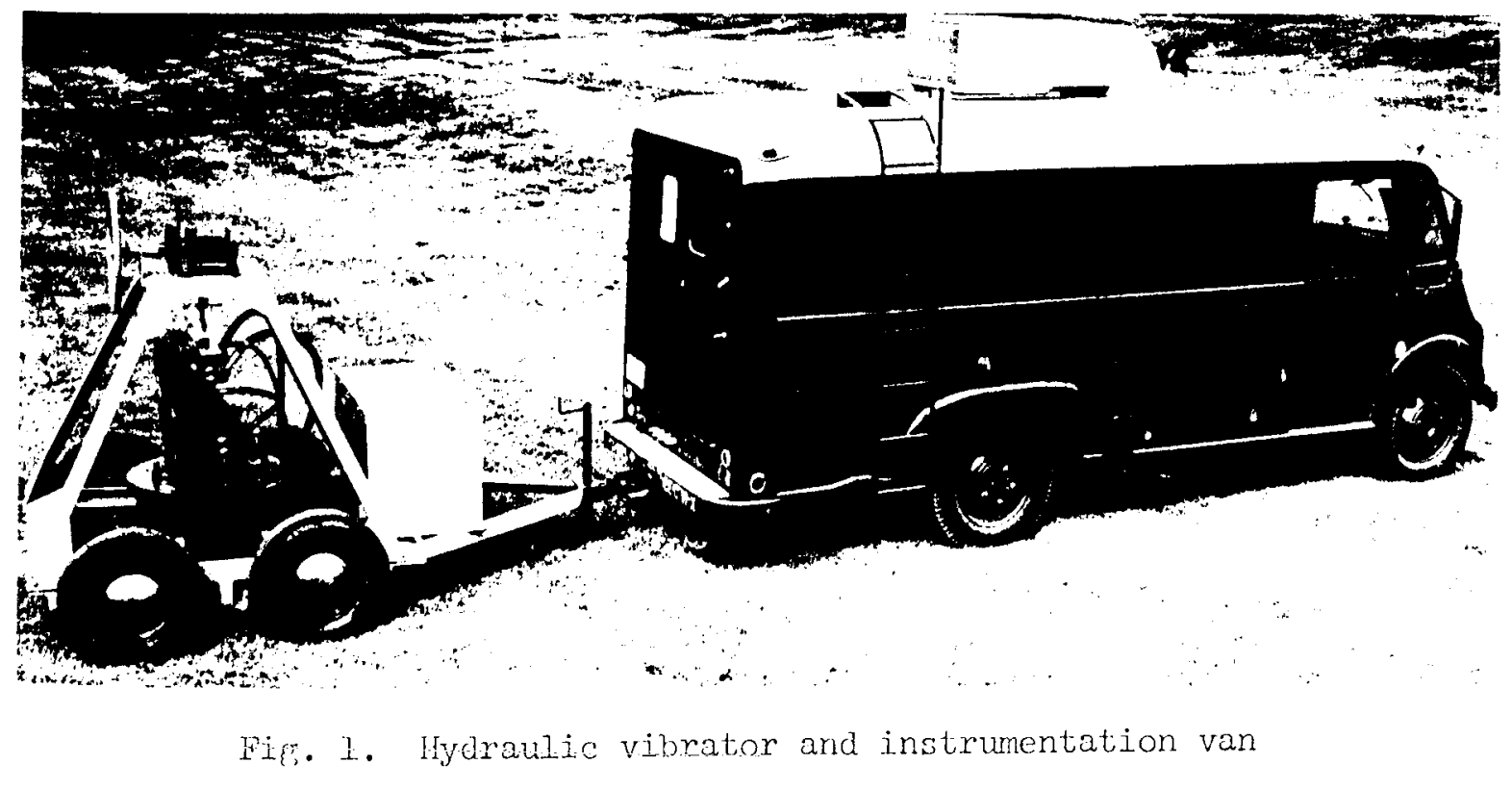

* U. S. Army Incineer Waterways ixperiment Station, CE, A Frocedure for Determining Flastic Moduli of Soils by Field Vibratory Techniques, by Z. B. Fry, Miscellaneous Paper No. 4-577 (Vicksburg, Miss., June 1963). 


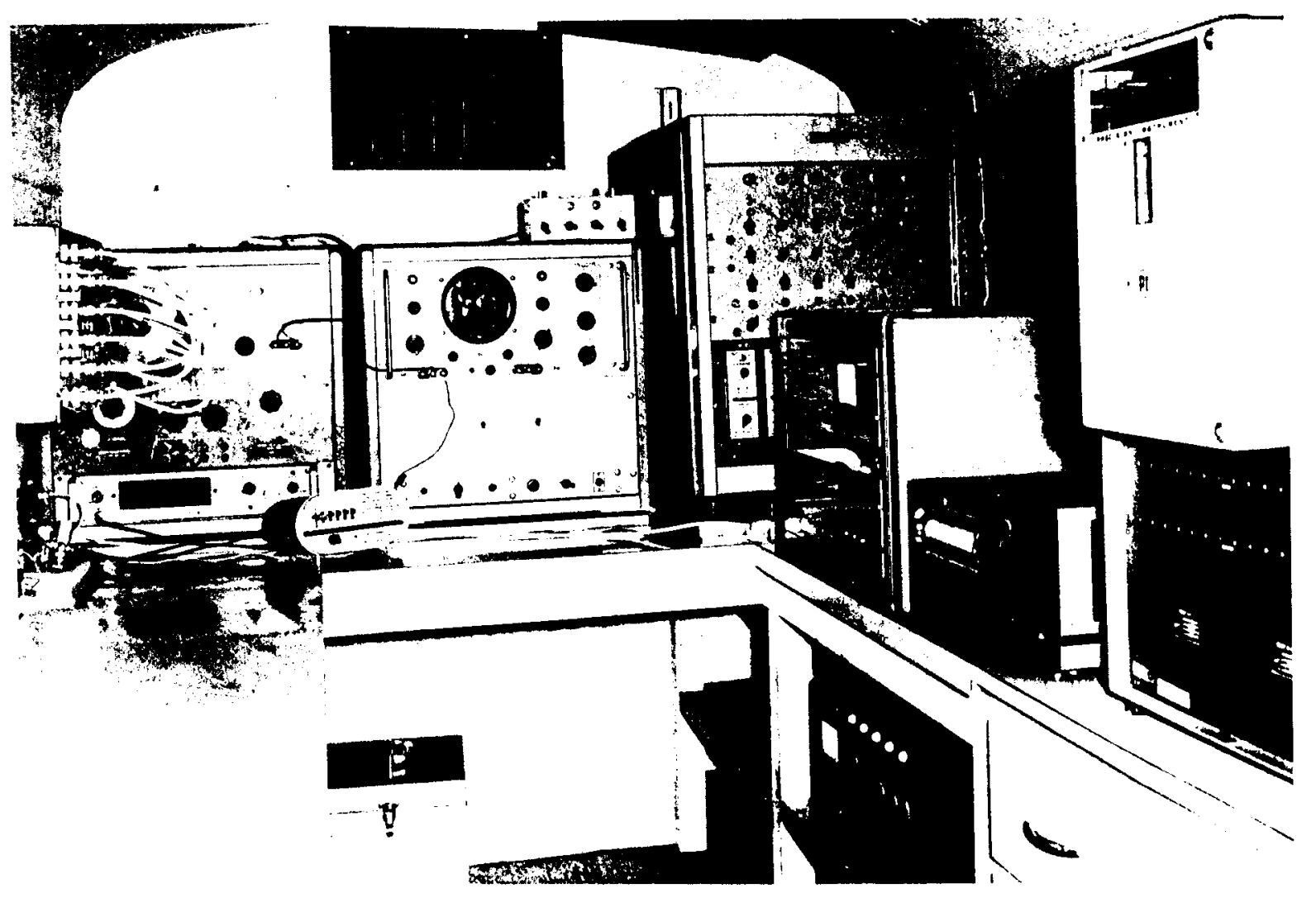

Fig. 2. Interior view of instrumentation van

Fig. 2 is a view of the truck interior showing instrumentation used for dynamic tests. The variable-mass vibrator is shown in detail in fig. 3 .

12. Test technique. The method employed to obtain test data was that described in WES Miscellaneous Paper 4-577.* This involves the use of sensitive transducers placed on the ground surface to measure the wavelength increments produced by surface-induced vibrations. Other methods considered to measure the shear-wave increments were (a) placing the vibrator at depths and a transducer on the surface, and (b) placing the vibrator on the surface and the transducers in boreholes. The first method was impractical due to the size of the vibrator and length of control equipment. The second method was attempted in the investigation at Flgin Field, Fla., but did not produce precise information.

\section{Equations Used in Data Reduction}

13. The equations used in data reduction were as follows:

* Cp. cit. 
Fig. 3. Variablemass hydraulic vibrator.

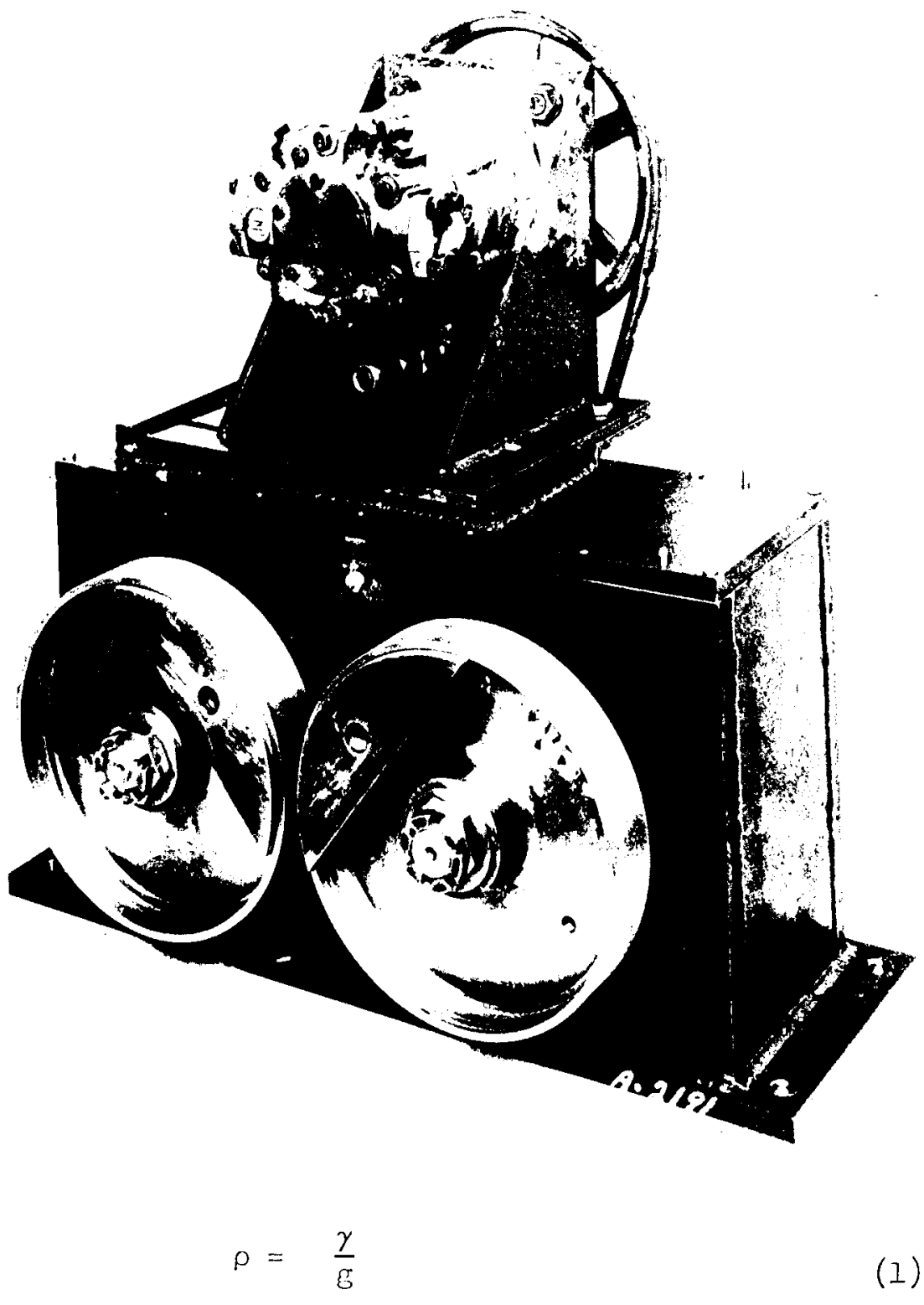

where

$\rho=$ mass density of soil, slugs per cu ft

$\gamma=$ wet unit woight of soiI, ib per cu it

$\varepsilon=$ acceleration due to cravity or 32.2 rt per sec per sec

$$
\text { Depth }=\frac{\lambda}{2}
$$

where

$\lambda=$ wavelength, $\mathrm{ft}$ 


$$
V=\lambda f
$$

where

$$
\begin{aligned}
& V=\text { wave velocity, fps } \\
& \lambda=\text { wavelength, ft } \\
& f=\text { frequency, cps }
\end{aligned}
$$

$$
G=\frac{V^{2} p}{144}
$$

where

$$
\begin{aligned}
& G=\text { shear modulus, } \mathrm{psi} \\
& \mathrm{V}=\text { wave velocity, fps } \\
& \rho=\text { mass density, slugs per cu ft }
\end{aligned}
$$

The derivation of these equations is discussed in Miscellaneous Faper 4-577.*

14. It should be noted that the test technique currently used by the WES to determine the dynamic elastic properties of soil materials was developed through the work of many consultants and specialists. Much of the basic theory and analytical work was performed by the Royal Dutch/shell. Laboratorium, Amsterdam, Holland. All but one of the equations presented above are widely used and theoretically correct for humogeneous, isotropic, elastic materials. The assumption which has not been theoretically validated is the use of the half vavelength as the depth of the propagated vave. This assumption, which is generally accepted, has been empirically validated by close correlation of dynamic test results with data obtaincd from numerous boreholes and test pits. These data are currently being utilized by the WES in a study to establish theoretical validation of the half vavelength as the approximate depth of wave penetration.

\section{Test Results}

\section{Pixed-mass vibrator}

15. The fixed-mass vibrator was used in tests at Eglin, Valdorf,

* Cp. cit. 
and Frenchman Flat. The depth attainable at Eglin was $20 \mathrm{ft}$, as shown in plate 2, and the shear moduli increased from 3800 psi at a depth of 1 ft to $8800 \mathrm{psi}$ at $20 \mathrm{ft}$. Soil materials at Waldorf were explored continuously to a depth of $37 \mathrm{ft}$, as shown in plate 3 , and the shear moduli increased from 2000 psi at the 1-ft depth to approximately 30,000 psi at $37 \mathrm{ft}$. Investigations at Frenchman Flat reached a depth of $45 \mathrm{ft}$, as shown in plate 4, with shear moduli increasing with depth from 2700 psi near the surface to 23,100 psi at $45 \mathrm{ft}$. The greatest depths at the three sites were representative of the maximum range of the fixed-mass vibrator. Variable-mass vibrator

16. The variable-mass vibrator, which was constructed in 1963, and the redesigned instrumentation (viz., a low-frequency band pass filter) significantly increased the depth from which calculations of shear moduli could be made. In initial vibratory check-out tests conducted with this equipment at the WES test site, waves extended to a depth of $62 \mathrm{ft}$ in the clay materials. The device was then utilized on rock materials at Sacramento Peal. During these tests, a second amplifier was added at the output of the pickup. This initial amplification (or preamplification) served essentially to increase the sensitivity of the pickup so that the extremely small amplitudes of the waves propagated through the rock could be detected. The success of this modification is evidenced in the data for Sacramento Peak shown in plate 5. Penetration exceeded $85 \mathrm{ft}$ and the shear moduli ranged from 33,600 psi at shallow depths to about 140,000 psi at a depth of $86 \mathrm{ft}$. Tests were conducted in areas of the Nevada Test site in which the preamplification process was used. Investigations at Buckboard Mesa (plate 6) extended to depths of $90 \mathrm{ft}$, with shear moduli increasing from about $1000 \mathrm{psi}$ at a depth of $1 \mathrm{ft}$ to $144,000 \mathrm{psi}$ at $90 \mathrm{ft}$. Tests in Area 15 at the Nievada Test Site penetrated to a depth of $170 \mathrm{ft}$, and the shear roduli ranged from 10,700 psi at $1.3 \mathrm{ft}$ to about 610,000 psi at $170 \mathrm{ft}$, as shown in plate 7 . These latter tests represent the greatest depths of penetration which have been attained by the WiS.

17. Additional vibratory tests to further determine the effectiveness of the preamplification technique were made at the same WES test site used in the check-out tests. The results of this investigation are shown in plate 8; note that the second series of tests not only confirmed the 
shear modulus values measured in the initial check-out to a depth of $62 \mathrm{ft}$, but also extended the effective depth of investigation to $120 \mathrm{ft}$. This was considered to verify the test procedure and technique. Shear moduli at the WES test site increased from 2300 psi near the surface to approximately 24,000 psi at a depth of $120 \mathrm{ft}$.

Discussion

18. The data summarized in table 2 were selected as representative of each test site, and are presented primarily to illustrate the progress made in extending the range of vibratory data to greater depths. The trend of shear modulus data collected at each site definitely indicated an increase in shear modulus with depth, which is reasonable and possibly attributable to increase in confining pressures at depth.

19. Wave penetration is influenced to some extent by the type of medium through which the wave is propagated. For practical purposes, the materials investigated in this study can be classified into three groups: rock, cohesive soil, and sand. The quality of sinusoidal wave shape and signal amplitude as displayed on the oscilloscope indicates that waves are propagated most easily through nonfractured rock material. Cohesive soil was the next best medium for transmissibility, followed by sand. Weathered materials and uneven or cracked surfaces adversely affect seating of the vibrator and transducer. The effect of these conditions can be minimized by leveling the soil surface and grouting the vibrator il test position, and by careful placement of the transducer.

20. The effect of water-table fluctuation upon data was not determined. However, tests conducted on sand several years ago at Cape Kennedy, Fla., indicated that fluctuation of the water table, if it is near the surface, does appear to slightly affect the tranomissibility of vibratory signals through this material. It should be noted that at the test sites referred to in this report the water tables were not near the surface.

\section{Summary of Results and Conclusions}

21. The variable-mass vibrator and associated instrumentation developed in this investigation permitted considerable extension of exploratory depths previously limited by the moderate force capabilities of the 
fixed-mass vibrator and by less-sensitive instrumentation. In the two types of soil investigated with the new equipment--rock and cohesive soil--test results indicated a shear modulus of 610,000 psi at a depth of $170 \mathrm{ft}$ in the rock material at Area 15, Nevada Test Site, and of 24,100 psi at a depth of $120 \mathrm{ft}$ in the cohesive material at WES.

22. It is concluded from the field test results that the vibratory equiprent and associated appurtenances at their present state of development provide a means of determining dynamic shear moduli at depths of approximately $100 \mathrm{ft}$ or more, depending upon site conditions and soil material. The variable-mass vibrator with improved instrumentation has not been tested on sand naterials; however, improvements in data acquisition in other materials lead to the cciclusion that the shear modulus of sand could almost certainly be determined at depths greater than the 20-ft depth investigated at Eglin with the fixed-mass vibrator. 
Table 1

Forces Generated by Fixed-Mass and Variable-Mass Hydraulic Vibrators

\begin{tabular}{|c|c|c|c|c|c|c|}
\hline \multirow{2}{*}{$\begin{array}{c}\text { Frequency } \\
\text { cps } \\
\end{array}$} & $\begin{array}{l}\text { Fixed-Mass } \\
\text { Vibrator* }\end{array}$ & \multicolumn{5}{|c|}{$\begin{array}{l}\text { Variable-Mass Vibrator Forces, } 1 \mathrm{~b} \text {, for Indicated } \\
\text { Total Weights of Eccentric Masses, Ib** }\end{array}$} \\
\hline & Forces, $1 \mathrm{~b}$ & 5.0 & 9.6 & 14.48 & 19.0 & 40.0 \\
\hline 1 & 3.8 & 2.1 & 4.0 & 6.0 & $7 \cdot 9$ & 16.6 \\
\hline 2 & 15.6 & 8.3 & 13.9 & 24.0 & 31.5 & 66.2 \\
\hline 3 & $3^{4}+.9$ & 18.4 & 35.3 & 53.2 & 69.8 & 147 \\
\hline 4 & 62.1 & 32.6 & 62.6 & 94.4 & 124 & 261 \\
\hline 5 & 97.0 & 51.0 & 97.9 & 148 & 194 & 408 \\
\hline 6 & 140 & 73.5 & 141 & 213 & 279 & 588 \\
\hline 7 & 191 & 100 & 192 & 290 & 380 & 801 \\
\hline 8 & 248 & 130 & 250 & 378 & 496 & 1,043 \\
\hline 9 & 314 & 165 & 317 & 478 & 627 & 1,321 \\
\hline 10 & 388 & 204 & 392 & 591 & 776 & 1,634 \\
\hline II & 470 & 247 & 475 & 716 & 939 & 1,977 \\
\hline 12 & 560 & 294 & 565 & 852 & 1,118 & 2,354 \\
\hline 13 & 656 & 345 & 662 & 998 & 1,310 & 2,758 \\
\hline 14 & 761 & 400 & 768 & 1158 & 1,519 & 3,199 \\
\hline 15 & 874 & 459 & 882 & 1330 & 1,746 & 3,675 \\
\hline 16 & 994 & 523 & 1004 & 1514 & 1,986 & 4,182 \\
\hline 17 & 1123 & 590 & 1134 & 1709 & 2,243 & 4,722 \\
\hline 18 & 1257 & 661 & 1269 & 3.914 & 2,512 & 5,288 \\
\hline 19 & 1401 & 736 & 1414 & 2133 & 2,799 & 5,892 \\
\hline 20 & 1553 & 816 & 1568 & 2364 & 3,103 & 6,532 \\
\hline 21 & 1713 & 901 & 1730 & 2608 & 3,422 & 7,205 \\
\hline 22 & 1880 & 989 & 1899 & 2863 & 3,756 & 7,909 \\
\hline 23 & 2053 & 1079 & 2072 & 3125 & 4,101 & 8,634 \\
\hline $2 \bar{l}_{4}$ & 2236 & 1175 & 2257 & 3404 & 4,467 & 9,404 \\
\hline 25 & 2427 & 1276 & 2450 & 3694 & 4,848 & 10,207 \\
\hline 26 & 2625 & 1380 & 2651 & 3997 & 5,244 & 11,041 \\
\hline 27 & 2832 & 1489 & 2860 & 4312 & 5,658 & 11,913 \\
\hline 28 & 3043 & 1600 & 3072 & 4633 & 6,079 & 12,799 \\
\hline 29 & 3265 & 1716 & 3296 & 4970 & 6,522 & 13,731 \\
\hline 30 & 3495 & 1837 & 3529 & 5321 & 6,982 & 14,700 \\
\hline 31 & 3731 & 1962 & 3768 & 5682 & 7,456 & 15,698 \\
\hline 32 & 3976 & 2091 & 4016 & 6055 & 7,946 & 16,729 \\
\hline 33 & 42283 & 2222 & 4267 & $64+34$ & 8,443 & 17,776 \\
\hline 34 & 4,4838 & 2350 & 4,531 & 6832 & 8,965 & 18,874 \\
\hline $3 t$ & 4756 & 2500 & 1,802 & 724.1 & 9,501 & 20,004 \\
\hline 36 & 5032 & 264.6 & 5081 & 7662 & 10,054 & 21,168 \\
\hline 37 & 5315 & 2706 & 5368 & 8095 & 10,623 & 22,364 \\
\hline 30 & 56,07 & $294 \%$ & 5659 & 8533 & 11,197 & 23,574 \\
\hline 39 & 5906 & 3104 & 5962 & 8989 & 11,796 & 24,834 \\
\hline 40 & 6212 & 3266 & 6272 & 9457 & 12,410 & 26,128 \\
\hline
\end{tabular}

* Eccontricity of the unbalanced mass e $=0.652 \mathrm{in}$; total of eccentric weishts $=58.2 \mathrm{lb}$.

$* *$ Eecontricity of the umblanced mass $e=4.0 \mathrm{in}$. 
Table 2

Summary of Test Results

\begin{tabular}{|c|c|c|c|c|c|c|c|}
\hline Test Site & $\begin{array}{l}\text { Wet Unit } \\
\text { Weight } \\
\gamma \\
1 \mathrm{~b} / \mathrm{cu} \mathrm{ft} \\
\end{array}$ & $\begin{array}{c}\text { Type } \\
\text { Vibrator } \\
\end{array}$ & $\begin{array}{l}\text { Fre- } \\
\text { quency } \\
\mathrm{f}, \mathrm{cps} \\
\end{array}$ & $\begin{array}{l}\text { Wave- } \\
\text { length } \\
\lambda, \text { ft } \\
\end{array}$ & $\begin{array}{l}\text { Depth } \\
\mathrm{ft} \\
\end{array}$ & $\begin{array}{l}\text { Wave } \\
\text { veloc- } \\
\text { ity } \\
\text { v, fps }\end{array}$ & $\begin{array}{l}\text { Shear } \\
\text { Modulus G, } \\
\text { psi } \times 10^{3}\end{array}$ \\
\hline \multirow[t]{2}{*}{$\begin{array}{l}\text { Eglin AFB, } \\
\text { Fla. }\end{array}$} & \multirow[t]{2}{*}{110} & $\begin{array}{l}\text { Electro- } \\
\text { magnetic }\end{array}$ & $\begin{array}{r}200 \\
125 \\
70 \\
50 \\
40 \\
30 \\
25 \\
20\end{array}$ & $\begin{array}{l}2.00 \\
3.10 \\
5.40 \\
8.00 \\
10.5 \\
15.2 \\
20.0 \\
27.1\end{array}$ & $\begin{array}{l}1.0 \\
1.6 \\
2.7 \\
4.0 \\
5.2 \\
7.6 \\
10.0 \\
13.6\end{array}$ & $\begin{array}{l}400 \\
390 \\
380 \\
400 \\
420 \\
455 \\
500 \\
540\end{array}$ & $\begin{array}{l}3.8 \\
3.6 \\
3.4 \\
3.8 \\
4.2 \\
4.9 \\
5.9 \\
6.9\end{array}$ \\
\hline & & $\begin{array}{l}\text { Hyd } \\
\text { fixed- } \\
\text { mass }\end{array}$ & 15 & 40.6 & 20.3 & 610 & 8.8 \\
\hline \multirow[t]{2}{*}{ Waltonf, lid. } & \multirow[t]{2}{*}{105} & $\begin{array}{l}\text { Electro- } \\
\text { magnetic }\end{array}$ & $\begin{array}{l}200 \\
150 \\
150 \\
120 \\
120 \\
100 \\
100 \\
90 \\
80 \\
80 \\
80 \\
70 \\
70 \\
65 \\
60 \\
50 \\
45 \\
35 \\
35 \\
30 \\
25\end{array}$ & $\begin{array}{l}1.62 \\
2.20 \\
1.87 \\
3.42 \\
3.27 \\
4.27 \\
4.00 \\
4.99 \\
6.72 \\
6.12 \\
0.45 \\
12.2 \\
12.3 \\
15.6 \\
15.6 \\
25.3 \\
28.4 \\
26.9 \\
28.0 \\
38.9 \\
50.4\end{array}$ & $\begin{array}{l}0.8 \\
1.1 \\
0.9 \\
1.7 \\
1.6 \\
2.1 \\
2.0 \\
2.5 \\
3.4 \\
3.1 \\
4.2 \\
6.1 \\
6.2 \\
7.8 \\
7.8 \\
12.6 \\
14.2 \\
13.4 \\
1.4 .0 \\
19.1 \\
25.2\end{array}$ & $\begin{array}{l}325 \\
330 \\
280 \\
410 \\
390 \\
425 \\
400 \\
450 \\
540 \\
490 \\
675 \\
855 \\
860 \\
1015 \\
935 \\
1.265 \\
1280 \\
940 \\
980 \\
11.05 \\
1260\end{array}$ & $\begin{array}{l}2.4 \\
2.5 \\
1.8 \\
3.8 \\
3.4 \\
4.1 \\
3.6 \\
4.6 \\
6.6 \\
5.4 \\
10.3 \\
16.6 \\
16.7 \\
23.3 \\
19.8 \\
36.2 \\
37.1 \\
20.0 \\
21.7 \\
30.7 \\
35.9\end{array}$ \\
\hline & & $\begin{array}{l}\text { Hyd } \\
\text { fixed- } \\
\text { mass }\end{array}$ & $\begin{array}{l}25 \\
20 \\
15\end{array}$ & $\begin{array}{l}46.7 \\
56.0 \\
73.7\end{array}$ & $\begin{array}{l}23.4 \\
28.0 \\
36.0\end{array}$ & $\begin{array}{l}1.170 \\
1120 \\
1.10^{4} j\end{array}$ & $\begin{array}{l}31.0 \\
20.4 \\
27.6\end{array}$ \\
\hline
\end{tabular}


Table 2 (Continued)

\begin{tabular}{|c|c|c|c|c|c|c|c|}
\hline Test Site & $\begin{array}{c}\text { Wet Unit } \\
\text { Weight } \\
\gamma \\
\mathrm{Ib} / \mathrm{cu} \text { ft } \\
\end{array}$ & $\begin{array}{c}\text { Type } \\
\text { Vibrator } \\
\end{array}$ & $\begin{array}{l}\text { Fre- } \\
\text { quency } \\
\text { f, cps } \\
\end{array}$ & $\begin{array}{l}\text { Wave- } \\
\text { length } \\
\lambda, \mathrm{ft} \\
\end{array}$ & $\begin{array}{c}\text { Depth } \\
\mathrm{ft} \\
\end{array}$ & $\begin{array}{l}\text { Wave } \\
\text { Veloc- } \\
\text { ity } \\
V \text {, fos } \\
\end{array}$ & $\begin{array}{l}\text { Shear } \\
\text { Modulus G, } \\
\text { psi } \times 10^{3} \\
\end{array}$ \\
\hline $\begin{array}{l}\text { Frenchman } \\
\text { Flat, Itev. } \\
\text { Test Site }\end{array}$ & $\begin{array}{l}89 \\
90 \\
90 \\
84 \\
90 \\
90 \\
90 \\
90 \\
93 \\
90 \\
90\end{array}$ & $\begin{array}{l}\text { Dlectro- } \\
\text { marnetic }\end{array}$ & $\begin{array}{l}200 \\
200 \\
150 \\
150 \\
125 \\
100 \\
100 \\
100 \\
80 \\
75 \\
75 \\
60 \\
50 \\
50 \\
45 \\
40 \\
40 \\
35 \\
30 \\
30 \\
25 \\
25 \\
25\end{array}$ & $\begin{array}{l}1.80 \\
1.88 \\
2.40 \\
1.91 \\
2.66 \\
4.00 \\
3.95 \\
3.75 \\
5.94 \\
6.81 \\
5.74 \\
9.38 \\
12.5 \\
11.2 \\
14.3 \\
18.2 \\
15.3 \\
20.6 \\
26.0 \\
24.0 \\
34.1 \\
31.1 \\
38.0\end{array}$ & $\begin{array}{l}0.9 \\
0.9 \\
1.2 \\
1.0 \\
1.3 \\
2.0 \\
2.0 \\
1.9 \\
3.0 \\
3.4 \\
2.9 \\
4.7 \\
6.2 \\
5.6 \\
7.2 \\
9.1 \\
7.6 \\
10.3 \\
13.0 \\
12.0 \\
17.0 \\
15.6 \\
19.0\end{array}$ & $\begin{array}{l}360 \\
375 \\
360 \\
285 \\
335 \\
400 \\
400 \\
375 \\
475 \\
510 \\
430 \\
565 \\
625 \\
560 \\
645 \\
725 \\
610 \\
720 \\
780 \\
720 \\
855 \\
780 \\
950\end{array}$ & $\begin{array}{l}2.7 \\
2.9 \\
2.7 \\
1.7 \\
2.3 \\
3.3 \\
3.3 \\
2.9 \\
4.6 \\
5.3 \\
3.8 \\
6.5 \\
7.5 \\
6.1 \\
8.1 \\
9.5 \\
7.2 \\
10.0 \\
11.8 \\
10.0 \\
14.7 \\
11.8 \\
17.5\end{array}$ \\
\hline & $\begin{array}{r}84 \\
93 \\
100 \\
98 \\
100 \\
102 \\
100 \\
91\end{array}$ & $\begin{array}{l}\text { Hyd } \\
\text { rixed- } \\
\text { mass }\end{array}$ & $\begin{array}{l}30 \\
25 \\
25 \\
20 \\
20 \\
15 \\
15 \\
12\end{array}$ & $\begin{array}{l}23.7 \\
31.1 \\
34.1 \\
43.1 \\
45.2 \\
62.2 \\
63.6 \\
90.3\end{array}$ & $\begin{array}{l}11.8 \\
15.6 \\
17.0 \\
21.6 \\
22.6 \\
31.1 \\
31.8 \\
45.2\end{array}$ & $\begin{array}{r}710 \\
780 \\
855 \\
860 \\
905 \\
935 \\
955 \\
1085\end{array}$ & $\begin{array}{r}9.1 \\
12.2 \\
15.8 \\
15.6 \\
17.6 \\
19.2 \\
19.7 \\
23.1\end{array}$ \\
\hline $\begin{array}{l}\text { Sacramento } \\
\text { Peak, } \\
\text { N. Mex. }\end{array}$ & .150 & $\begin{array}{l}\text { Electro- } \\
\text { magnetic }\end{array}$ & $\begin{array}{r}300 \\
250 \\
200 \\
160 \\
140 \\
140 \\
130 \\
110 \\
100 \\
50\end{array}$ & $\begin{array}{c}3.40 \\
4.40 \\
4.95 \\
7.18 \\
10.8 \\
9.59 \\
12.0 \\
16.7 \\
23.7 \\
45.2\end{array}$ & $\begin{array}{l}1.7 \\
2.2 \\
2.5 \\
3.6 \\
5.4 \\
4.8 \\
6.0 \\
8.4 \\
11.8 \\
22.6\end{array}$ & $\begin{array}{r}1020 \\
1100 \\
990 \\
1150 \\
1510 \\
1345 \\
1560 \\
1840 \\
2370 \\
2260\end{array}$ & $\begin{array}{l}33.6 \\
39.1 \\
31.7 \\
42.8 \\
73.7 \\
58.5 \\
78.7 \\
109 \\
182 \\
165\end{array}$ \\
\hline
\end{tabular}


Table 2 (Continued)

\begin{tabular}{|c|c|c|c|c|c|c|c|}
\hline Test Site & $\begin{array}{l}\text { Wet Unit } \\
\text { Weight } \\
\quad \gamma \\
\mathrm{Ib} / \mathrm{cu} \text { ft } \\
\end{array}$ & $\begin{array}{c}\text { Type } \\
\text { Vibrator } \\
\end{array}$ & $\begin{array}{l}\text { Fre- } \\
\text { quency } \\
\mathrm{f}, \mathrm{cps} \\
\end{array}$ & $\begin{array}{l}\text { Wave- } \\
\text { length } \\
\underline{\lambda,} \text { ft } \\
\end{array}$ & $\begin{array}{l}\text { Depth } \\
\mathrm{ft} \\
\end{array}$ & $\begin{array}{l}\text { Wave } \\
\text { Veloc- } \\
\text { ity } \\
\text { v, fps }\end{array}$ & $\begin{array}{l}\begin{array}{l}\text { Shear } \\
\text { Modulus G, } \\
\text { psi } \times 10^{3}\end{array} \\
\end{array}$ \\
\hline $\begin{array}{l}\text { Sacramento } \\
\text { Peak, } \\
\text { N. l'ex. } \\
\text { (Cont'd) }\end{array}$ & 150 & $\begin{array}{l}\text { Hyd } \\
\text { variable- } \\
\text { mass }\end{array}$ & $\begin{array}{l}30 \\
30 \\
25 \\
25 \\
20 \\
20 \\
18 \\
18 \\
14.5 \\
14 \\
12 \\
12\end{array}$ & $\begin{array}{l}57.5 \\
60.0 \\
76.7 \\
92.0 \\
98.6 \\
125 \\
115 \\
138 \\
138 \\
153 \\
153 \\
172\end{array}$ & $\begin{array}{l}28.8 \\
30.0 \\
38.4 \\
46.0 \\
49.3 \\
62.5 \\
57.5 \\
69.0 \\
69.0 \\
76.5 \\
76.5 \\
86.0\end{array}$ & $\begin{array}{l}1725 \\
1800 \\
1920 \\
2300 \\
1970 \\
2500 \\
2070 \\
2485 \\
2000 \\
2140 \\
1835 \\
2065\end{array}$ & $\begin{array}{l}96.2 \\
105 \\
119 \\
171 \\
126 \\
202 \\
138 \\
200 \\
129 \\
1483 \\
109 \\
138\end{array}$ \\
\hline $\begin{array}{l}\text { Buckboard } \\
\text { Mesa, } \\
\text { Nevada Test } \\
\text { Site }\end{array}$ & 145 & $\begin{array}{l}\text { Electro- } \\
\text { magnetic }\end{array}$ & $\begin{array}{r}120 \\
80 \\
73 \\
65 \\
60 \\
55 \\
50 \\
45 \\
40 \\
35\end{array}$ & $\begin{array}{l}1.84 \\
4.34 \\
6.79 \\
9.40 \\
12.1 \\
15.9 \\
19.7 \\
23.8 \\
29.8 \\
38.7\end{array}$ & $\begin{array}{r}0.9 \\
2.2 \\
3.4 \\
4.7 \\
6.0 \\
8.0 \\
9.8 \\
11.9 \\
14.9 \\
19.4\end{array}$ & $\begin{array}{l}220 \\
345 \\
495 \\
610 \\
725 \\
875 \\
985 \\
1070 \\
1190 \\
1355\end{array}$ & $\begin{array}{l}1.0 \\
2.4 \\
5.0 \\
7.6 \\
10.8 \\
15.7 \\
19.9 \\
35.8 \\
44.3 \\
57.4\end{array}$ \\
\hline & 170 & $\begin{array}{l}\text { Hyd } \\
\text { variable- } \\
\text { mass }\end{array}$ & $\begin{array}{l}25 \\
20 \\
18 \\
15 \\
13 \\
12 \\
11\end{array}$ & $\begin{array}{l}38.9 \\
50.0 \\
73.7 \\
93.3 \\
108 \\
140 \\
180\end{array}$ & $\begin{array}{l}19.4 \\
25.0 \\
36.8 \\
46.6 \\
54.0 \\
70.0 \\
90.0\end{array}$ & $\begin{array}{l}975 \\
1000 \\
1325 \\
1400 \\
1405 \\
1680 \\
1980\end{array}$ & $\begin{array}{l}29 \cdot 7 \\
31.3 \\
54 \cdot 9 \\
61.3 \\
72.3 \\
103 \\
144\end{array}$ \\
\hline $\begin{array}{l}\text { Area } 15, \\
\text { Nevada Test } \\
\text { Site }\end{array}$ & 170 & $\begin{array}{l}\text { Electro- } \\
\text { magnetic }\end{array}$ & $\begin{array}{r}200 \\
100 \\
80 \\
70 \\
60 \\
50 \\
40 \\
30 \\
25\end{array}$ & $\begin{array}{c}2.69 \\
7.62 \\
9.93 \\
11.7 \\
15.7 \\
19.3 \\
25.4 \\
32.8 \\
43.6\end{array}$ & $\begin{array}{r}1.3 \\
3.8 \\
5.0 \\
5.8 \\
7.8 \\
9.6 \\
12.7 \\
16.4 \\
21.8\end{array}$ & $\begin{array}{r}540 \\
760 \\
795 \\
820 \\
940 \\
965 \\
1015 \\
985 \\
1090\end{array}$ & $\begin{array}{l}10.7 \\
21.2 \\
23.2 \\
24.6 \\
32.4 \\
34.1 \\
37.8 \\
35.6 \\
43.5\end{array}$ \\
\hline & & $\begin{array}{l}\text { Hyd } \\
\text { variable- } \\
\text { mass }\end{array}$ & $\begin{array}{l}25 \\
20 \\
13 \cdot 3 \\
12\end{array}$ & $\begin{array}{l}43.6 \\
63.0 \\
200 \\
340\end{array}$ & $\begin{array}{r}21.8 \\
31.5 \\
100.0 \\
170.0\end{array}$ & $\begin{array}{l}1000 \\
1260 \\
2660 \\
4080\end{array}$ & $\begin{array}{l}43.5 \\
58.2 \\
259 \\
610\end{array}$ \\
\hline
\end{tabular}


Table 2 (Concluded)

\begin{tabular}{|c|c|c|c|c|c|c|c|}
\hline Test Site & $\begin{array}{c}\text { Wet Unit } \\
\text { Weight } \\
\gamma \\
\text { Ib/cu ft } \\
\end{array}$ & $\begin{array}{c}\text { Type } \\
\text { Vibrator } \\
\end{array}$ & $\begin{array}{c}\text { Fre- } \\
\text { quency } \\
\mathrm{f}, \text { cps } \\
\end{array}$ & $\begin{array}{l}\text { Wave- } \\
\text { length } \\
\lambda, \mathrm{ft} \\
\end{array}$ & $\begin{array}{c}\text { Depth } \\
\text { ft } \\
\end{array}$ & $\begin{array}{l}\text { Wave } \\
\text { Veloc- } \\
\text { ity } \\
\text { V, fps } \\
\end{array}$ & $\begin{array}{c}\text { Shear } \\
\text { Modulus } G, \\
\text { psi } \times 10^{3}\end{array}$ \\
\hline \multirow[t]{3}{*}{$\begin{array}{l}\text { WES, } \\
\text { Vicksburg, } \\
\text { Miss. }\end{array}$} & 120 & $\begin{array}{l}\text { Electro- } \\
\text { magretic }\end{array}$ & $\begin{array}{r}400 \\
200 \\
100 \\
75 \\
50 \\
40 \\
35 \\
30 \\
25\end{array}$ & $\begin{array}{l}0.75 \\
1.87 \\
4.20 \\
5.70 \\
9.40 \\
12.2 \\
17.1 \\
19.8 \\
22.2\end{array}$ & $\begin{array}{l}0.4 \\
0.9 \\
2.1 \\
2.8 \\
4.7 \\
6.1 \\
8.6 \\
9.9 \\
11.1\end{array}$ & $\begin{array}{l}300 \\
375 \\
420 \\
430 \\
470 \\
490 \\
600 \\
595 \\
555\end{array}$ & $\begin{array}{l}2.3 \\
3.6 \\
4.6 \\
4.8 \\
5.7 \\
6.2 \\
9.3 \\
9.2 \\
8.0\end{array}$ \\
\hline & & $\begin{array}{l}\text { Hyd } \\
\text { variable- } \\
\text { mass, } \\
\text { first } \\
\text { series }\end{array}$ & $\begin{array}{r}20 \\
10 \\
9 \\
8 \\
7 \\
6\end{array}$ & $\begin{array}{c}27.0 \\
57.0 \\
67.0 \\
85.6 \\
109 \\
124\end{array}$ & $\begin{array}{l}13.5 \\
28.5 \\
33.5 \\
42.8 \\
54.5 \\
62.0\end{array}$ & $\begin{array}{l}540 \\
570 \\
605 \\
685 \\
765 \\
745\end{array}$ & $\begin{array}{r}7.5 \\
8.4 \\
9.5 \\
12.1 \\
15.1 \\
14.4\end{array}$ \\
\hline & & $\begin{array}{l}\text { Hyd } \\
\text { variable- } \\
\text { mass, } \\
\text { second } \\
\text { series }\end{array}$ & $\begin{array}{l}10 \\
9 \\
8 \\
6 \\
5 \\
4.5 \\
4.25 \\
4\end{array}$ & $\begin{array}{l}58.8 \\
70.2 \\
83.3 \\
111 \\
140 \\
174 \\
189 \\
241\end{array}$ & $\begin{array}{r}29.4 \\
35.1 \\
41.6 \\
55.5 \\
70.0 \\
87.0 \\
94.5 \\
120.5\end{array}$ & $\begin{array}{l}590 \\
630 \\
665 \\
665 \\
700 \\
785 \\
805 \\
965\end{array}$ & $\begin{array}{r}9.0 \\
10.3 \\
11.4 \\
11.4 \\
12.6 \\
15.9 \\
16.8 \\
24.1\end{array}$ \\
\hline
\end{tabular}




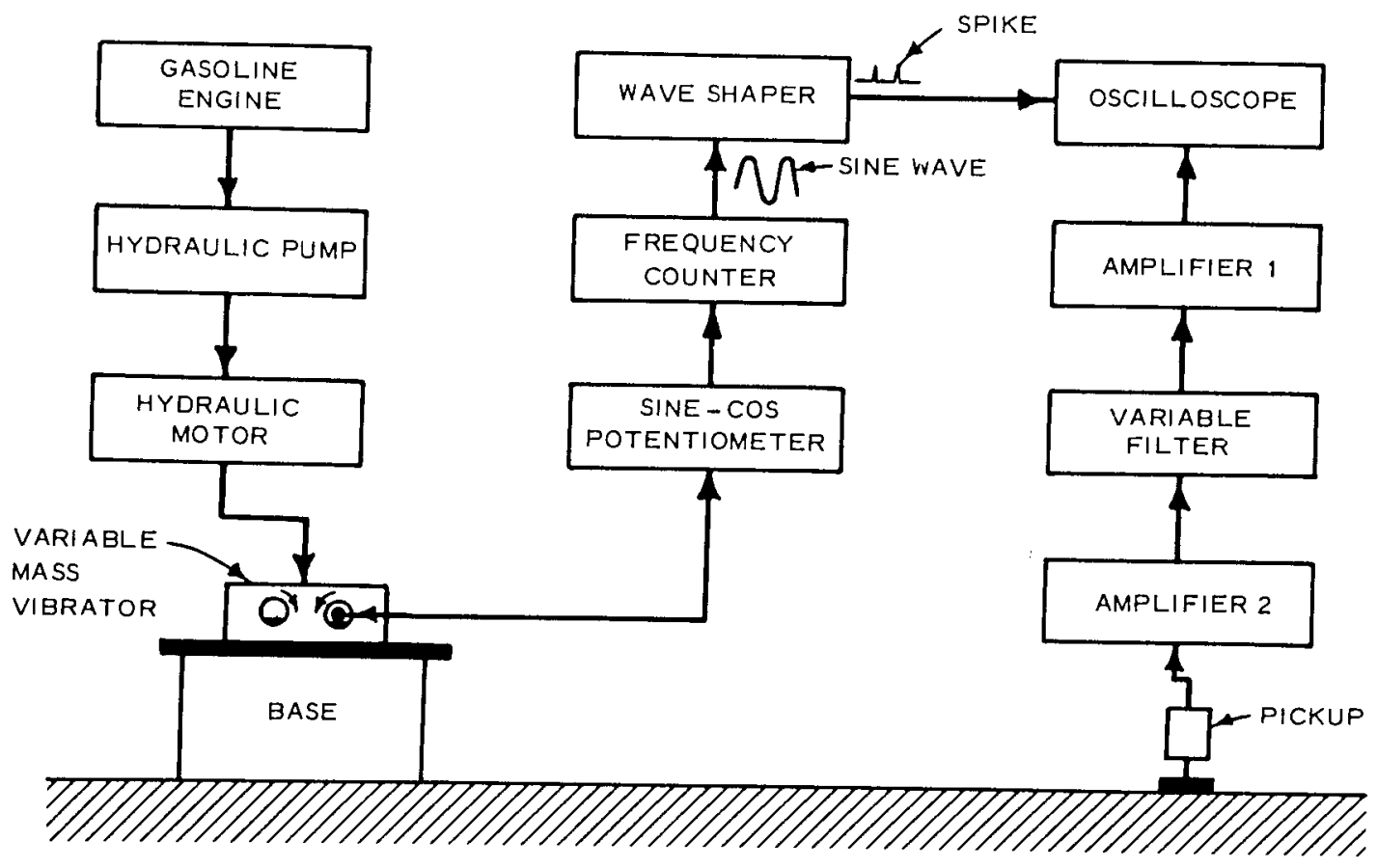

BLOCK DIAGRAM

EQUIPMENT LIST

\begin{tabular}{lll}
\hline \multicolumn{1}{c}{ ITEM } & & \multicolumn{1}{c}{ MAKE AND MODEL } \\
\cline { 1 - 1 } VIBRATOR & & WES-CONSTRUCTED COUNTERROTATING VARIABLE \\
HASS ECCENTRIC WEIGHTS & MYRAULIC TRANSMISSION POWER & NEW YORK AIR BRAKE COMPANY "DYNAPOWER" \\
SINE-COSINE POTENTIOMETER & & COMPUTER INSTRUMENTS CORPORATION 206 \\
FREQUENCY COUNTER & & HEWLETT-PACKARD 5512A \\
WAVE SHAPER & WES-CONSTRUCTED \\
OSCILLOSCOPE & HEWLETT-PACKARD 130BR \\
AMPLIFIER NO. 1 & ALINCO 516-A \\
VARIABLE BAND PASS FILTER & ALLISON 201 \\
AMPLIFIER NO. 2 & ALINCO 516-A \\
VELOCITY PICKUP & PHILLIPS PR9260 \\
\hline
\end{tabular}

\author{
BLOCK DIAGRAM \\ FOR LOW-FREQUENCY \\ VARIABLE-MASS VIBRATOR \\ AND ASSOCIATED EQUIPMENT
}

PLATE I 

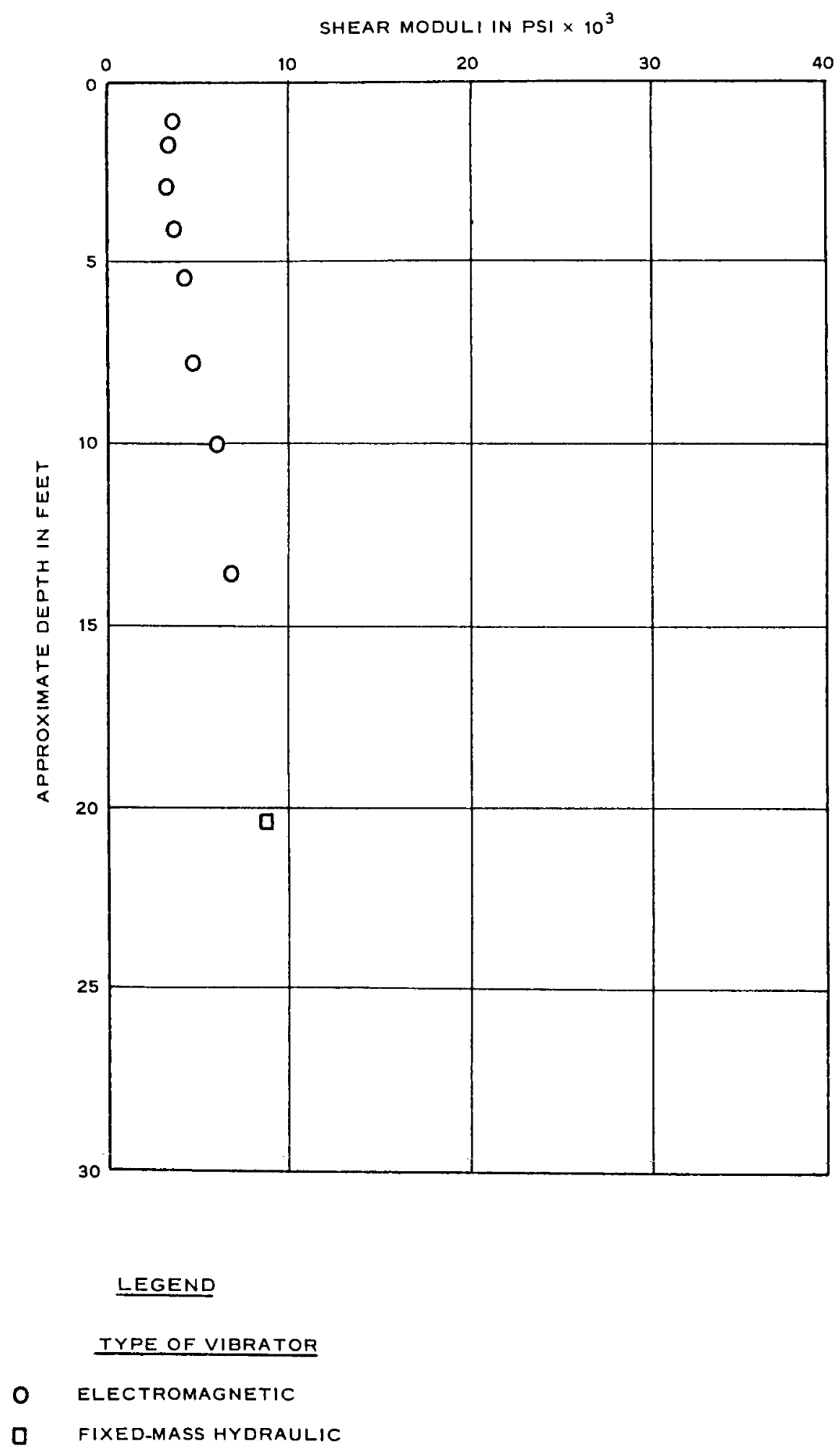

SHEAR MODULI VS DEPTH

EGLIN AFB, FLORIDA 


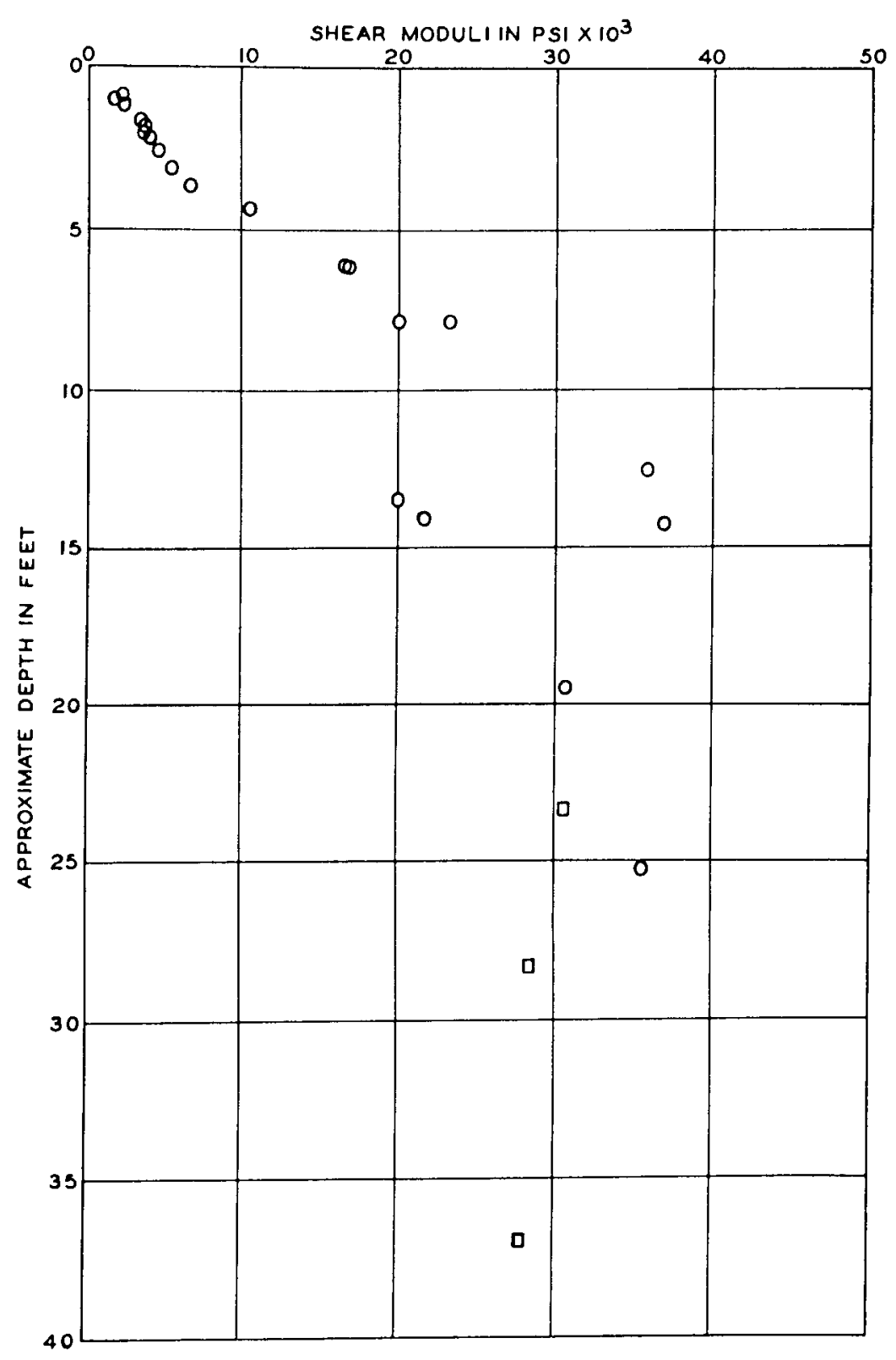

\footnotetext{
LEGEND

TYPE OF VIBRATOR

- ELECTROMAGNETIC

D FIXED-MASS HYDRAULIC
}

SHEAR MODULI VS DEPTH

WALDORF, MARYLAND 


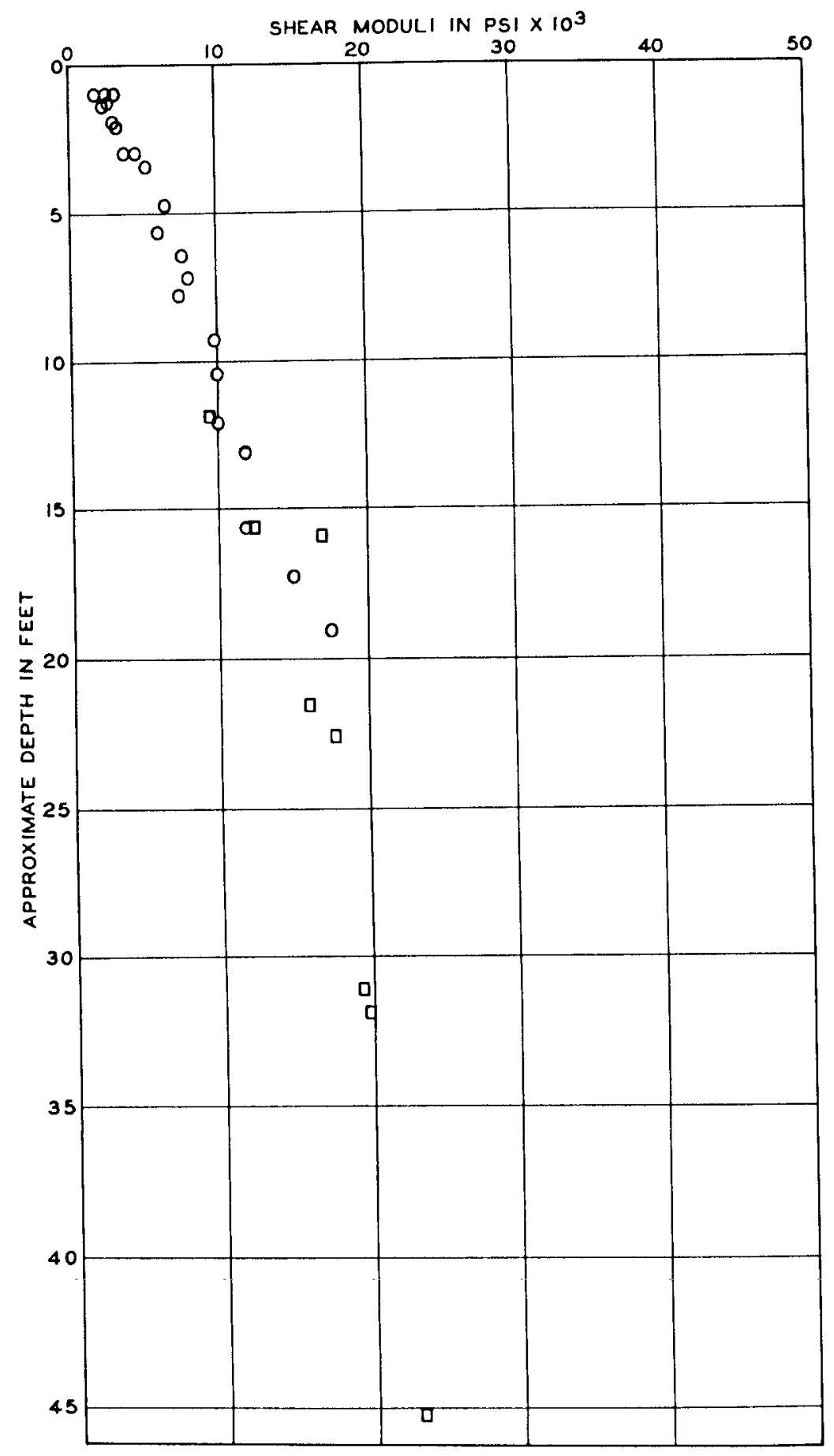

\section{LEGEND}




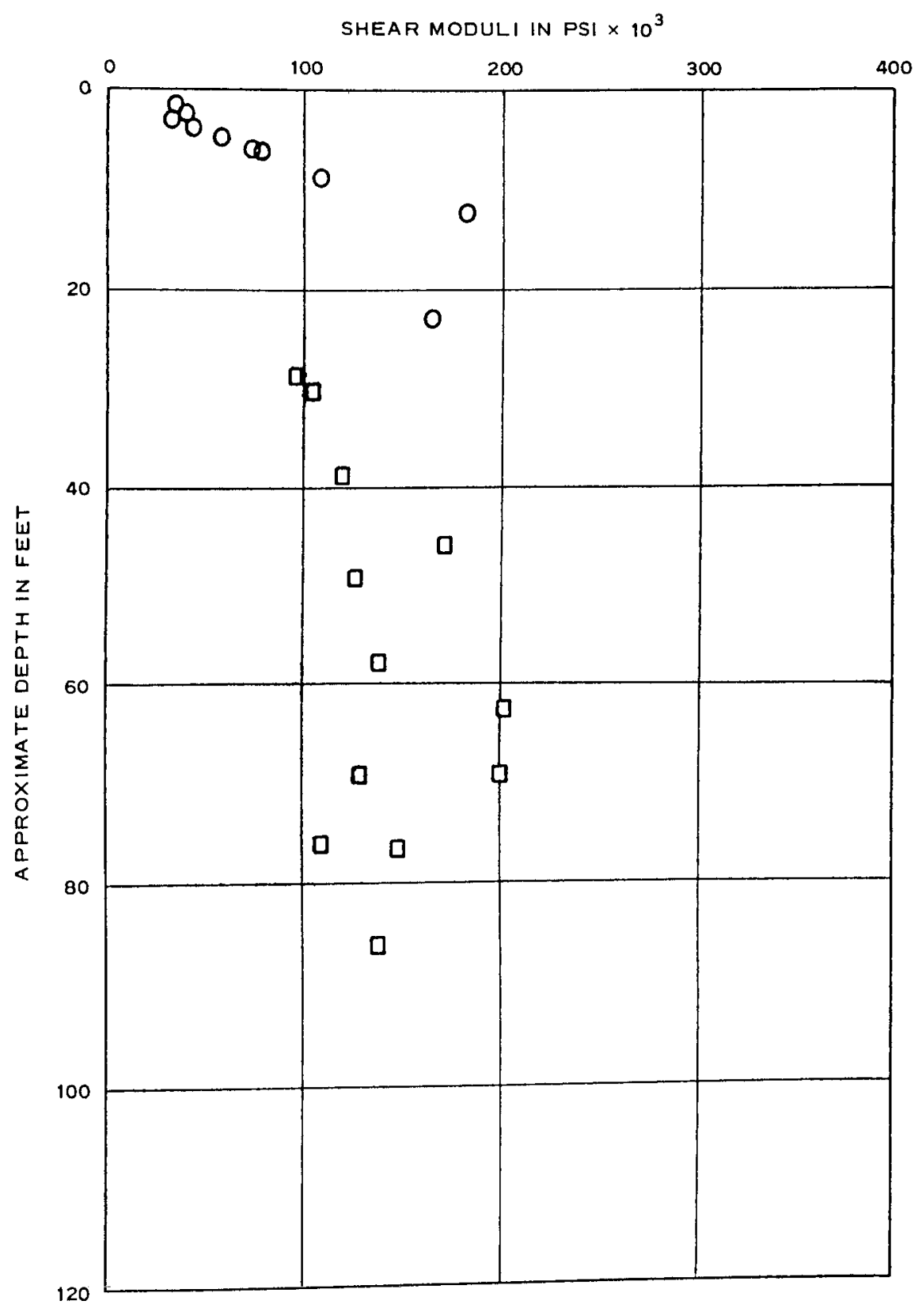

\section{LEGEND}

\section{TYPE OF VIBRATOR}

- electromagnetic

D VARIABLE-MASS HYDRAULIC 


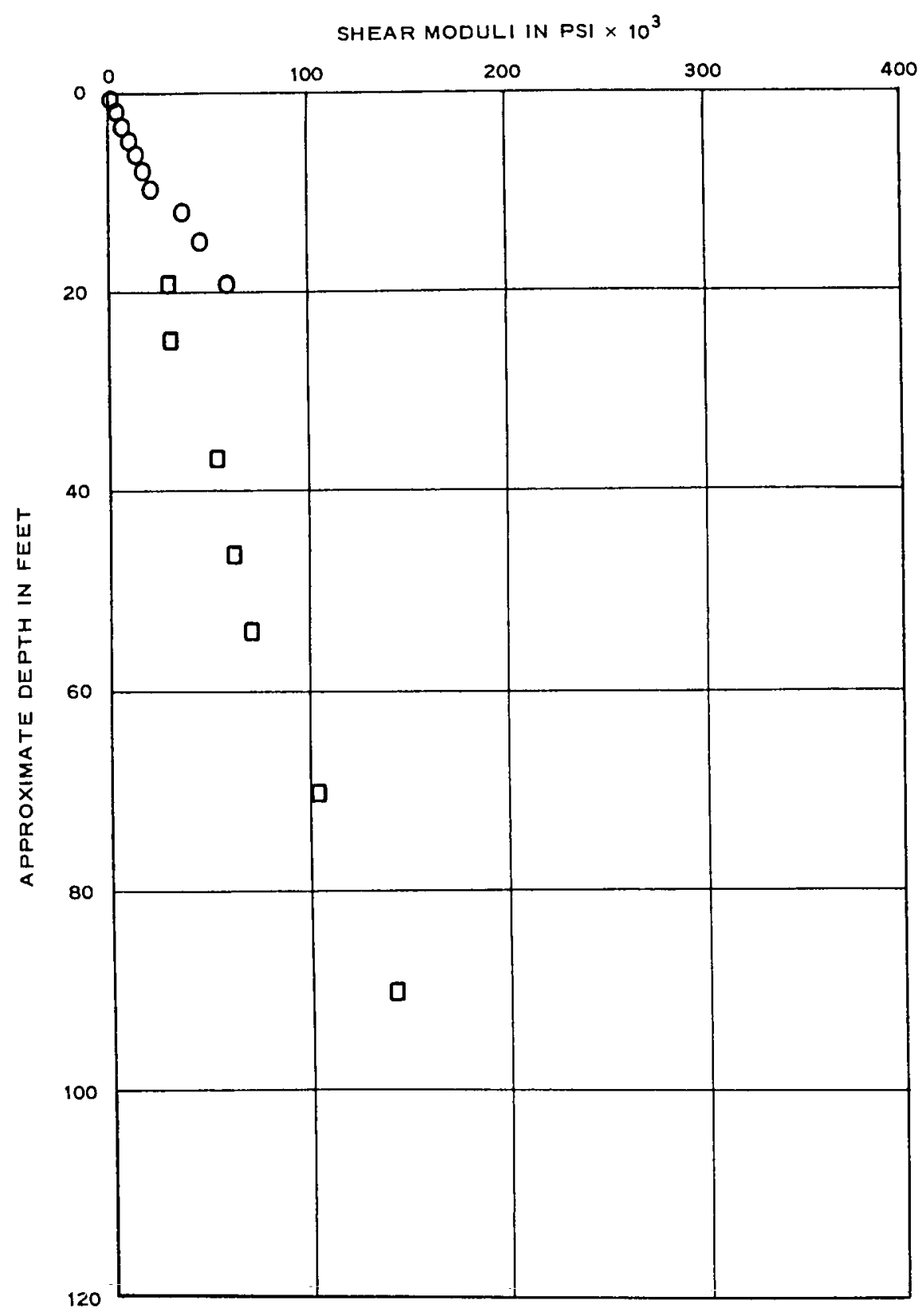

LEGEND

\section{IYPE OF VIBRATOR}

- Electromagnetic

a VARIABLE-MASS HYDRAULIC

SHEAR MODULI VS DEPTH

BUCKBOARD MESA, NEVADA TEST SITE 

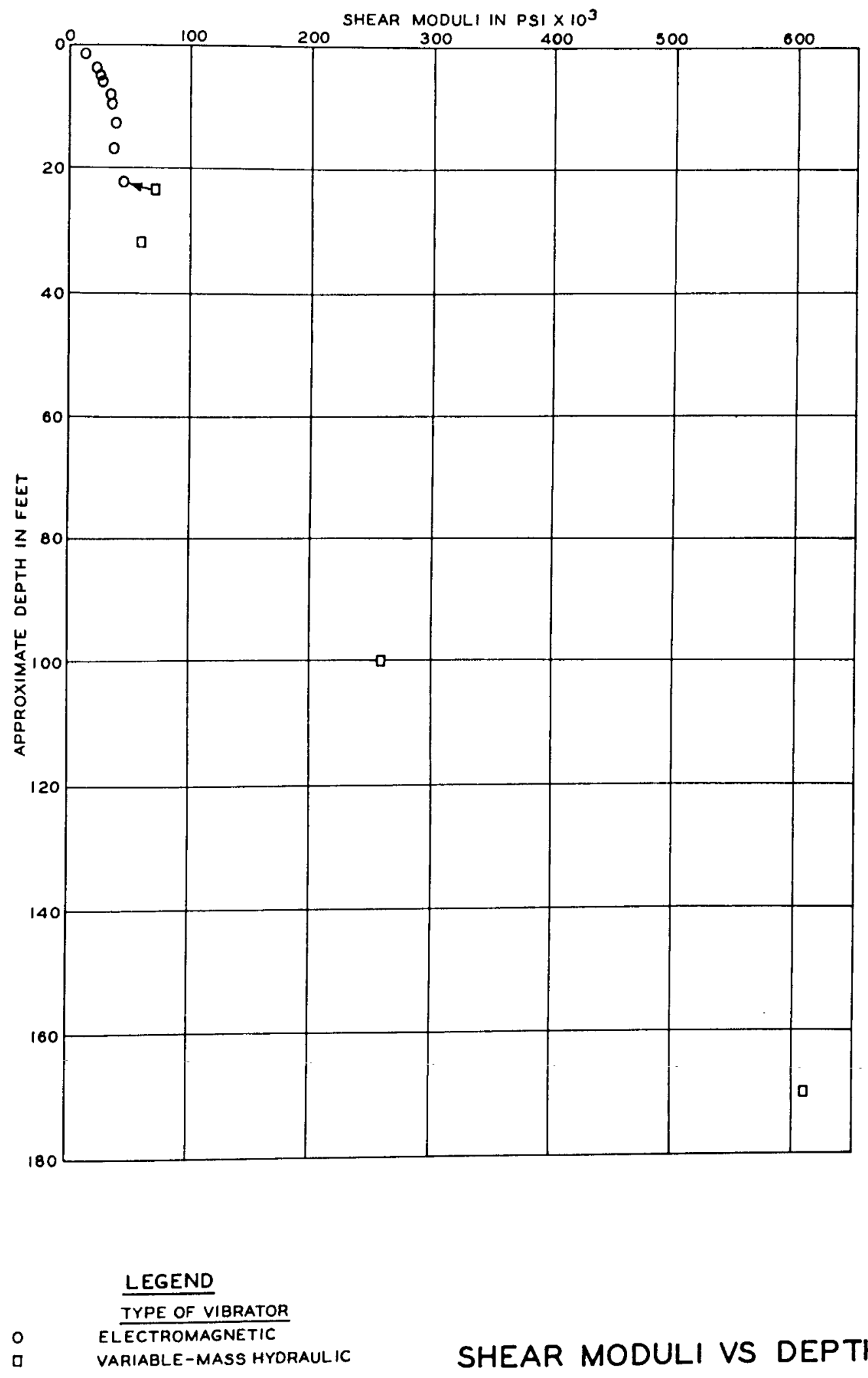

SHEAR MODULI VS DEPTH

AREA 15, NEVADA TEST SITE 


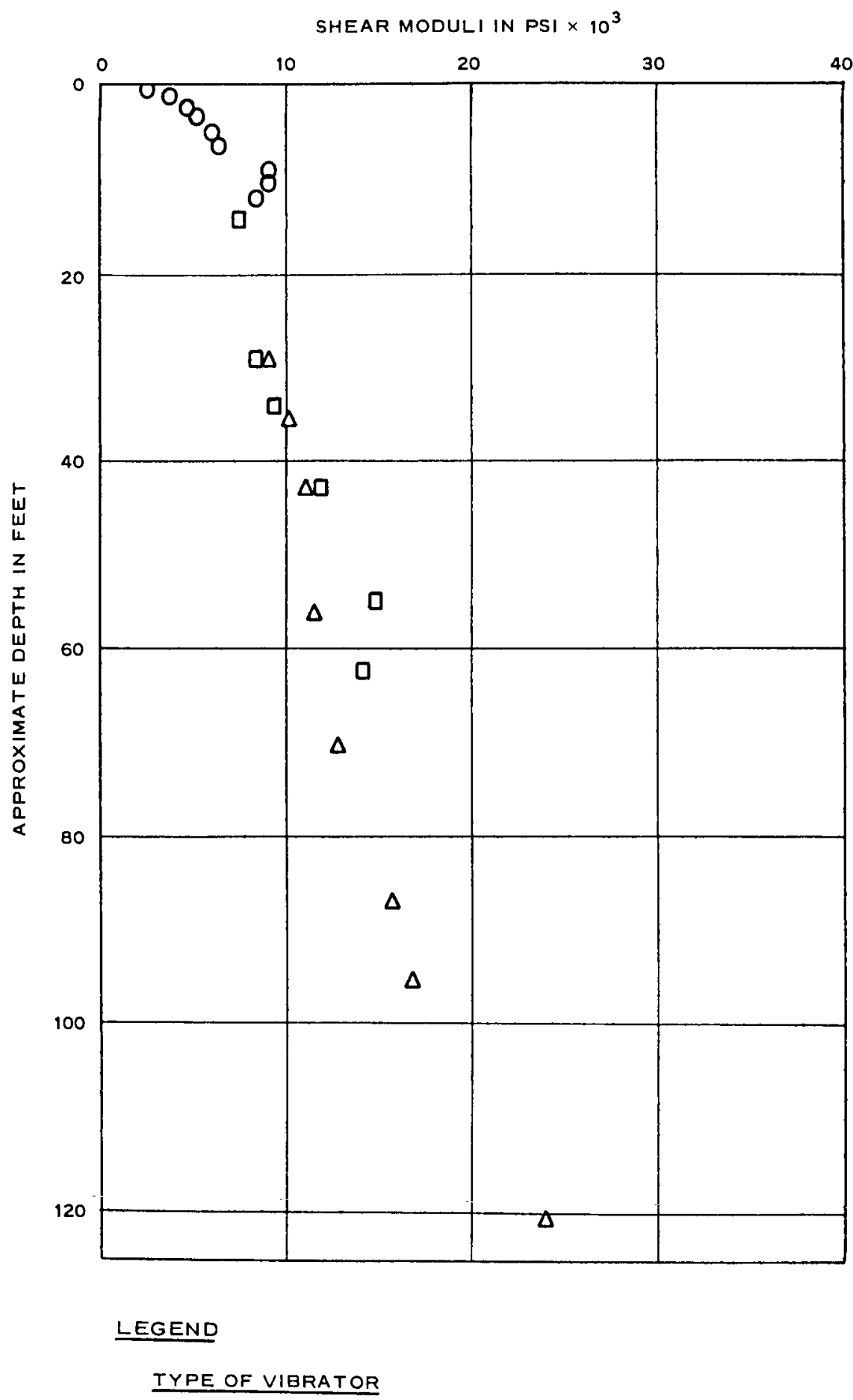

FIRST SERIES

0

口

SECOND SERIES

$\Delta$
ELECTROMAGNETIC

VARIABLE-MASS HYDRAULIC

SHEAR MODULI VS DEPTH

WES, VICKSBURG, MISSISSIPPI 
APFEIDIX A

FRCJECT ORDER 


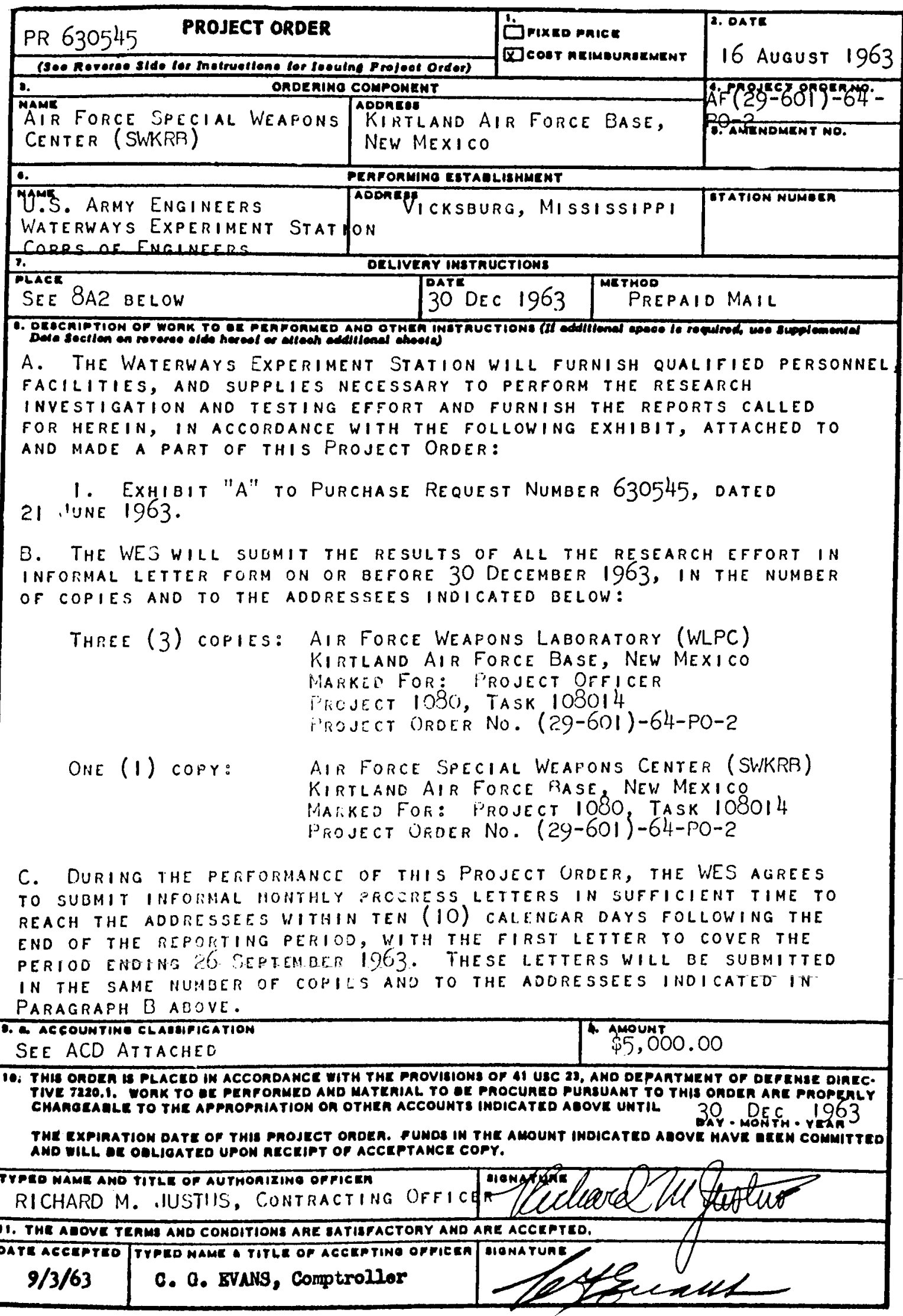




\section{INSTRUCTIONS}

This farin lo Intended tor use by components of millery departmente In placine project orders with Governmont. owned and operaled etteblishments within and outelde the Department of Defento.

ITEM 1 - Check eppropelate box Indlcating type of profect order; Le., fixed price or cost relmburement.

ITEM 2 - Date of project order or amendinent.

ITEM 3 - Name and eddrese of ordering component.

ITEM 4 - Number anelened to project oeder by ordering component for control pupones.

ITEM 5 - Number asigned to project order amendment by orderine component for control pusposes. Formal amendmente thall be numbered coneccutively.

ITEM 6 - Name, addrese, and atation number of performe lan exabllohment.

TTEM 7 - Inetructlone for place, date and mothod of deIlvery, if applicable. If additional opece is required, uee Suppleonental Date section below.

TTEM 8 - Full deecription of the work ordered fthil may be incorporafed by soferance) and auch other inutruct tone as condutions of Inspectlons, thlpplac, pecklns and marking, ofc. Ute Supplemontal Data section or attach additional woets If necennary. Limitallons, If any, applicable to the appropelatione or other account relevant to this order are shown in the Supplomental Data Section below.

ITEM 9 - Inwert the complete account in claselficetlon chargeable and the amount of the project order or amendment.

ITEM 10 - Incert in the epaces provided, the explestion date of the project order, the namo, thle and - ignature of offlcer or hle authorlsed repeosentallve controlling or hoving responelblllty for the adminte. itration of the fund clted on the project arder or amondmont. If authorlzing olflcer is other than one having flacel reaponelblilty, the ordering department muat have on the an support to the certificate, a wiltton elatement by euch an ofleer aubientafles the flecal pertion of the certlificate.

ITEM 11 - The performing entabliahmont shall Indleate ecceptance In this epece. Dupllcate, bearing ecceptance date, name, title and elgature of accepting oflicer thall be rot urned to the ordering component. It the performing - etabllahme re is unable to accept ipe project order, it hall return promptly the octelacl projoct order form to the ordering office with approprlate explenation.

\section{REIMBURSEMENT WILL SUPPLEMENTAL DATA SECTION \\ WILL BE MADE ON A MONTHLY BASIS, AND WILL BE BASEB ON SUBMISSION OF SF 1080 . SF $1080^{\prime} \mathrm{S}$ WILL BE SUBMITTED FOR PROCESSING}

TO:

AFSWC (SWKRB)

Kirtlano aIr force rase, New Mexico

E. The Cognizant air force administrative Office for this project ORDER IS:

AFSWC (SWKRD)

Kirtland Air force Base, New Mexico

F. The Cognizant air force technical office for this project order Is:

AFWL (WLRS)

kirtland air force base, New Mexico

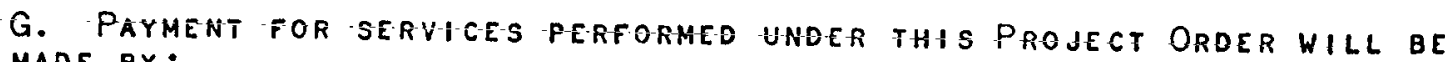
MADE BY:

\section{AFSWC (SWCAT)}

Kirtland Air Force base, New Mexico

H. ACCEPTANCE. FINAL ACCEPTANCE OF THE WORK CALLED FOR UNDER THIS PROJECT ORDER WILL BE MADE UNDER THE GUIDANCE AND SUPERVISION OF THE AIR Force WEapons laboratory PROJECT SCIENTIST. Formal ACCEPTANCE (I SSUANCE OF DD FORM 250, "MATERIAL INSPECTION AND RECEIVING REPORT," WILL BE BASED ON ACCEPTANCE OF THE ITE:4 CAI.ED FOR IN PARAGRAPH R OF THIS SCHEDULE. 


\section{UNCLASSIFIEO}

Exh1bit "A" to Purchase Request 630545

Air Force Systems Command

Research and Technology Division

Atr Force Weapons Laboratory

21 JUNE 1963

Statement of Work

for

Vibratory Soil Experiments

1. SCOPE: The scope of the work includes the use of available equipment, personnel, and field sites to investigate the determination of shear moduli at depths from surface induced vibrational energy.

2. OBJECTIVE: The objective of this work is to investigate the possibility of measuring cyclic shear wave energy at depth from surface induced vibrations. The final product of this research effort will be the determination of soil shear modulus in a continuous profile to 100 feet depths.

3. DETAIIED OUTLINE OF WORK:

3.1. The contractor shall use existing equipment to investigate the measurement of cyclic shear energy by either: length increments.

3.1.1. Placing geophones in boreholes to measure shear wave

3.1.2. Placing the vibrator at various depths and record with geophones on the ground surface.

3.1.3. Use sufficiently sensitive geophones to make surface measurements of wave length increments from surface induced vibrations.

3.2. The final produce of this research effort shall be a letter type report which summarizes the techniques and results. 


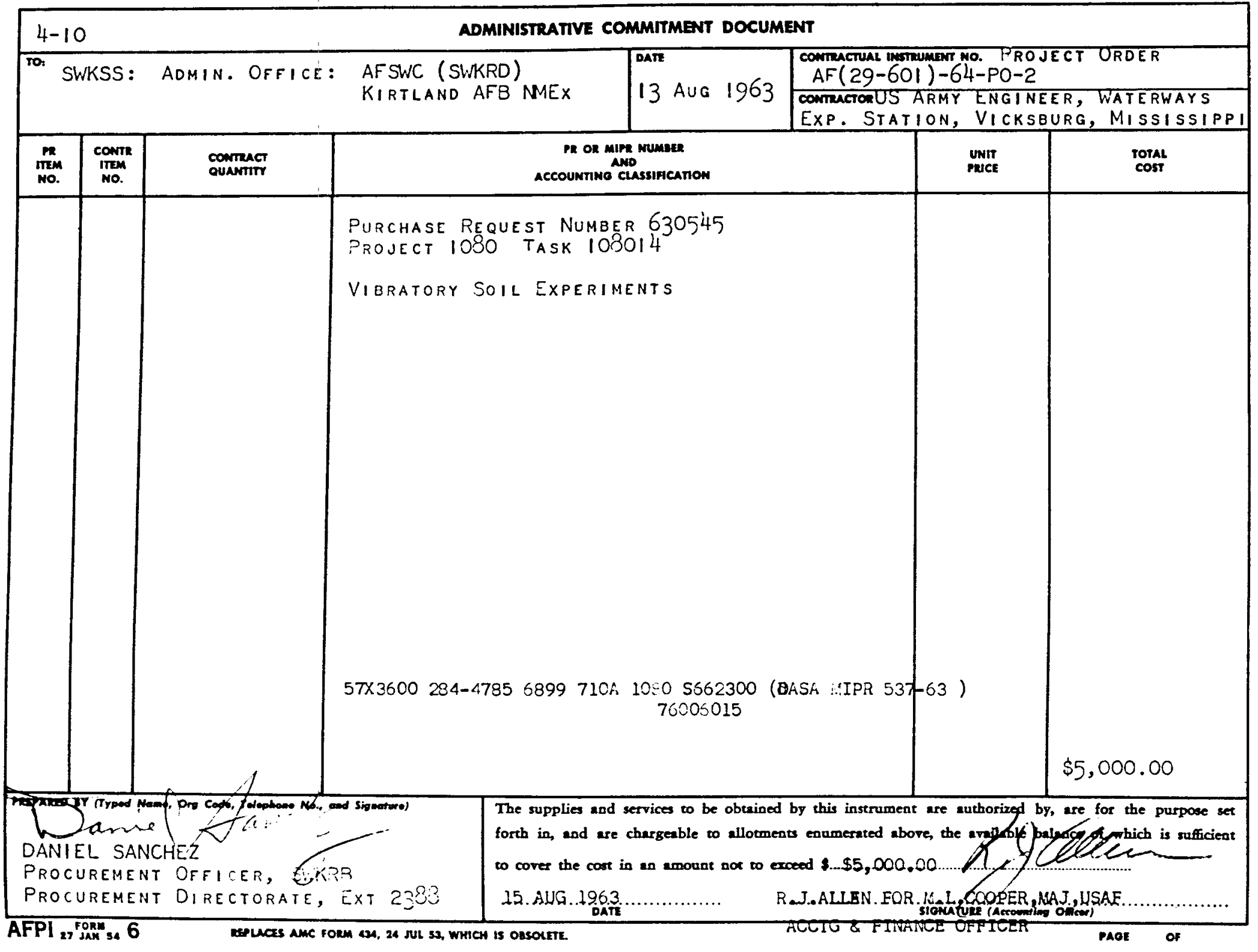

